九州大学学術情報リポジトリ

Kyushu University Institutional Repository

\title{
Cucumber Mosaic Virus in Bangladesh
}

\section{Akanda, Abdul Mannan}

Laboratory of Plant Pathology, Faculty of Agriculture, Kyushu University

Tsuno, Kazunori

Laboratory of Plant Pathology, Faculty of Agriculture, Kyushu University

Maeda, Takanor i

Research Institute for Bioresources, Okayama University

Wakimoto, Satoshi

Laboratory of Plant Pathology, Faculty of Agriculture, Kyushu University

https://doi.org/10.5109/23960

出版情報 : 九州大学大学院農学研究院紀要. 35 (3/4)，pp.151-159，1991-02. Kyushu University バージョン：

権利関係： 


\title{
Cucumber Mosaic Virus in Bangladesh
}

\author{
Abdul Mannan Akanda, Kazunori Tsuno, Takanori Maeda* \\ and Satoshi Wakimoto \\ Laboratory of Plant Pathology, Faculty of Agriculture, \\ Kyushu University, Fukuoka 812, Japan \\ *Research Institute for Bioresources, Okayama University, Kurashiki 710
}

(Received October 30,1990)

\begin{abstract}
As many as 92 different samples belonging to 15 botanical families, showing virus disease-like symptom were collected from various locations of Bangladesh in 1986-87. Plant samples were lyophilized or dried with calcium chloride and preserved at $4{ }^{\circ} \mathrm{C}$. Since inactivation of most of the samples was observed in mechanical inoculation to original or closely related host plants in 1989, the dried samples were subjected to double antibody sandwich enzyme-linked immunosorbent assay (DAS-ELISA) and dot-immunobinding assay (DIBA) for detecting cucumber mosaic virus (CMV). Two, three, two and one of the samples of cucumber, chilli, pepper and tomato, respectively, were found to be positive against the antiserum of CMV in DAS-ELISA. Of these eight samples, six reacted positively in DIBA. Simplified double-diffusion (SDD) test was also applied to detect CMV from dried samples. All these three methods DAS-ELISA, DIBA and SDD test were found to be useful for the detection of CMV from dried samples. Results demonstrated that the antigenicity of CMV retained at least for 2-3 years after drying even if they had completely lost their infectivity. The results also suggested the occurrence of CMV on cucurbitaceous and solanaceous plants in Bangladesh, but its distribution frequency seemed not so high.
\end{abstract}

\section{INTRODUCTION}

Bangladesh, a predominately agro-based country, grows many varities of crops such as legumes, vegetables, fibres, spices etc. as major food and cash crops (Rabbani, 1984 ; Rashid, 1976 ; Rashid, 1981). High prevalence of plant diseases has been reported to limit the yield and quality of crops there (Talukder, 1974 ; Ahmed, 1984). Fakir (1984) reported that hot-humid-tropical climate is one of the main reasons which favours the catastrophic occurrence of plant diseases on various crops in Bangladesh. Among these, the diseases caused by viruses have been found to be high on the basis of the symptomatological observation (Ahmed, 1984). The actual cause of these diseases have not yet been identified due to lack of proper facilities and trained manpower to investigate the plant viruses. However, the identification of viruses infecting various crops is highly important to combat the diseases.

Cucumber mosaic virus (CMV) has been reported to be one of the most economically important aphid-borne viruses infecting a wide variety of hosts including herba ceous and woody plants all over the world (Franki et al.,1979). It has been reported that 775 plant species belonging to 85 families are said to be susceptible to CMV and the highest number of susceptible hosts are listed in Cruciferae, Solanaceae, Compositae, Leguminosae and Cucurbitaceae (Lovisolo, 1981). The virus has been given special attention due to its complex epidemiology as it is transmitted by several 
aphid species and through seeds of some hosts and also due to its serious damage to crop production (Cohen, 1982 ; Jones, 1988 ; Conti and Lovisolo, 1982 ; Martelli and Quacgarelli, 1982 ; Phillips and Burnt, 1985). Although, Lovisolo (1981) reported the severe occurrence of CMV on many crops specifically in the temperate zone, its occurrence on various crops has also been reported from the south and south east, tropical asian countries (Kajiwara and Konno, 1986 ; TARC, 1977).

This study was, therefore, undertaken to make a serological survey on the occurrence of CMV on different crops in Bangladesh by using dried specimens.

\section{MATERIALS AND METHODS}

Plant sample used

In all 92 samples representing 39 plant species of 15 botanical families were collected from various fields located in seven different adminstrative districts of Bangladesh in 1986-87 (Table 1). the leaves of plants showing virus disesae-like symptom were collected and dried by lyophilization or with calcium chloride. The dried samples were preserved at $4^{\circ} \mathrm{C}$ until use.

Inoculation test

All the samples were inoculated to the original hosts and some common local lesion hosts such as Chenopodium quinoa, C. amaranticolor, Gomphrena globosa, Nicotianatabacum, N. glutinosa, Cucumis sativus, Pisum sativum etc. following the

Table 1. List of the samples collected in Bangladesh.

\begin{tabular}{rll} 
No. & \multicolumn{1}{c}{ Plant samples } & Symptom \\
\hline \multicolumn{2}{c}{ CUCURBITACEAE } & \\
$* 1$ & Bottlegourd & Mosaic \\
2 & Bottlegourd & Vein-clearing \\
3 & Bottlegourd & Mosaic \\
$* 4$ & Bottlegourd & Mosaic \\
5 & Bottlegourd & Yellowing \\
6 & Bittergourd & Mosaic, Curl \\
7 & Bittergourd & Mosaic \\
$* 8$ & Cucumber & Mosaic \\
9 & Cucumber & Yellowing \\
10 & Cucumber & Mosaic \\
$* 11$ & Pumpkin & Mosaic \\
12 & Pumpkin & Mosaic \\
13 & Round cucumber & Mosaic \\
14 & Spongegourd & Mosaic, Vein-clearing \\
15 & Sweetgourd & Mosaic \\
16 & Whitegourd & Mosaic \\
17 & Zucchini & Mosaic \\
SOLANACEAE & Chilli & Curl \\
18 & Yhilli & Yellowing, Curl \\
19 & Chilli & Vein-clearing \\
20 & Chilli & Mosaic \\
$* 21$ & Chilli & Mosaic \\
22 & Eggplant & \\
23 &
\end{tabular}

Location

Nurbag ${ }^{1)}$, Gazipur ${ }^{2}$ Mouckak, Gazipur Gazipur, Gazipur Kashimpur, Gazipur Kashimpur, Gazipur Joydebpur, Gazipur Kashimpur, Gazipur Kashimpur, Gazipur Kashimpur, Gazipur Jessore, Jessore Kashimpur, Gazipur Salna, Gazipur Joydebpur, Gazipur Charpolisha, Jamalpur Katabari, Jamalpur Kashimpur, Jamalpur Joydebpur, Gazipur

Kashimpur, Gazipur Joydebpur, Gazipur Ragunathpur, Jamalpur Kashimpur, Gazipur Salna, Gazipur Nutonhat, Jessore 


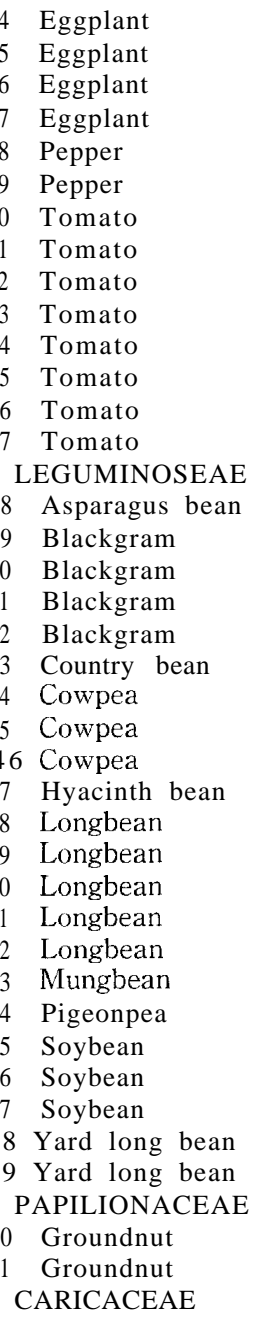

*62 Papaya

*63 Papaya

64 Papaya

*65 Papaya

*66 Papaya

67 Papaya

CRUCIFERAE

68 Cauliflower

69 Chinese cabbage

70 Chinese cabbage

71 Chinese cabbage

72 Chinese cabbage

73 Radish

MALVACEAE

74 Cotton

75 Cotton

Mosaic
Yellowing
Vein-clearing
Mosaic
Curl
Enation
Curl
Purple
Yellowing
Curl
Necrosis
Purple
Crinkle
Yellowing
Yellowing
Mosaic
Mottle
Yellow mosaic
Mosaic, Chlorosis
Mosaic
Mosaic, Vein-clearing
Mosaic
Mosaic
Mosaic
Mosaic
Necrosis
Shrinking
Yellow spots
Yellowing
Curl, Mottle
Mosaic
Mosaic
Mosaic
Mosaic
Vein-clearing
Mosaic
Yellowing
Mosaic
Fern leaf
Mein-clearing
Mosaic
Mosaic
Vein-clearing
Mosaic
Mosaic
Mosaic
Mosaic
Yellowing
Curl

Morosic
Mosaic
Mosic

Kashimpur, Gazipur

Kashimpur, Gazipur

Kashimpur, Gazipur

Salna, Gazipur

Gazipur, Gazipur

Kashimpur, Gazipur

Joydebpur, Gazipur

Joydebpur, Gazipur

Kashimpur, Gazipur

Salna, Gazipur

Salna, Gazipur

Salna, Gazipur

Salna, Gazipur

Salna, Gazipur

Salna, Gazipur

Pars, Jamalpur

Pars, Jamalpur

Rahmatpur, Barisal

Nashopur, Dinajpur

Salna, Gazipur

Jessore, Jessore

Salna, Gazipur

Joydebpur, Gazipur

Bhaorber, Jessore

Kashimpur, Gazipur

Kashimpur, Gazipur

Kashimpur, Gazipur

Kashimpur, Gazipur

Kashimpur, Gazipur

Gabua, Patuakhali

Ragunathpur, Jamalpur

Salna, Gazipur

Ishurdi, Pabna

Kashimpur, Gazipur

Joydebpur, Gazipur

Joydebpur, Gazipur

Rahmatpur, Barisal

Loknathpur, Chuadanga

Kashimpur, Gazipur

Joydebpur, Gazipur

Kashimpur, Gazipur

Salna, Gazipur

Patuakhali, Patuakhali

Salna, Gazipur

Salna, Gazipur

Kashimpur, Gazipur

Kashimpur, Gazipur

Kashimpur, Gazipur

Kashimpur, Gazipur

Salna, Gazipur

Basherhat, Dinajpur

Basherhat, Dinajpur 


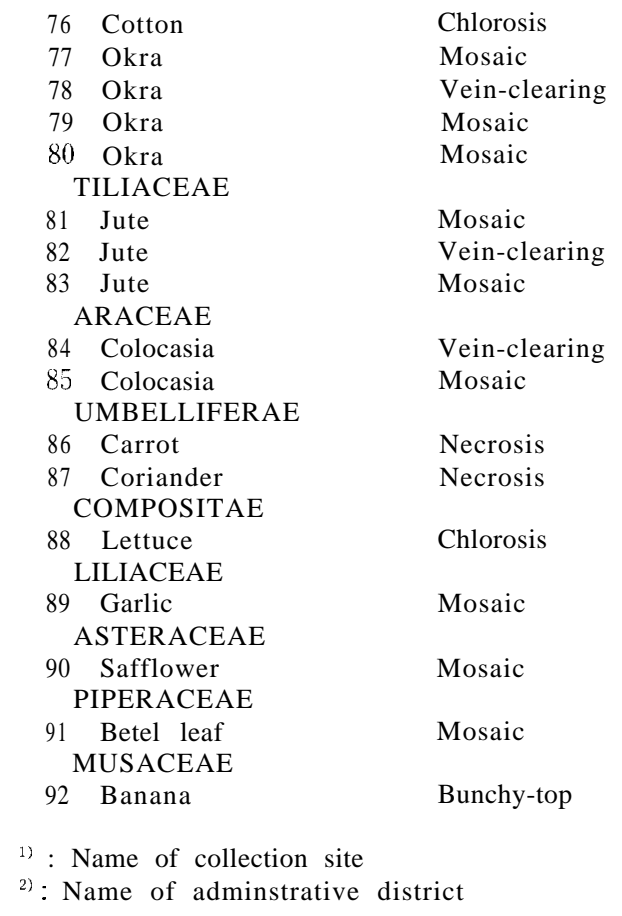

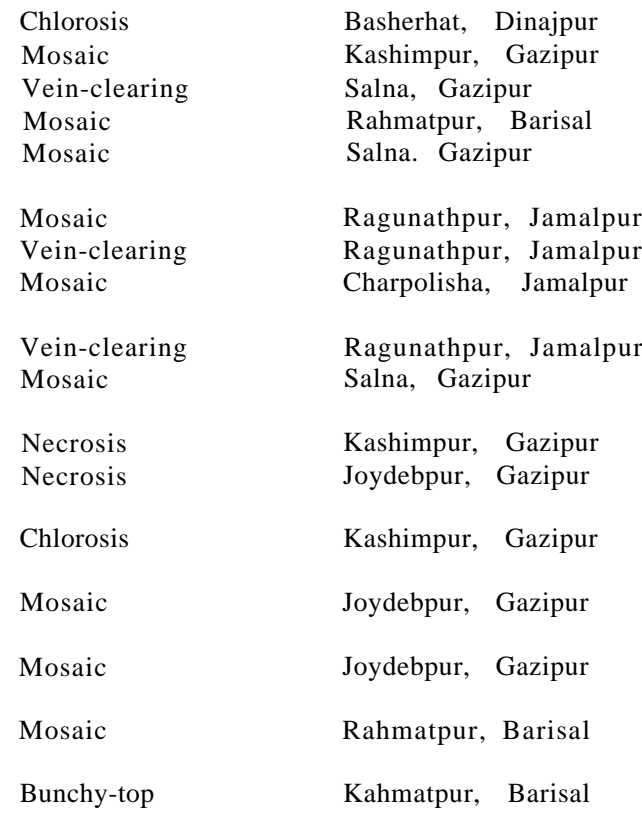

methods of Hill (1984). Inoculations were done in a temperature controlled greenhouse $\left(20-25^{\circ} \mathrm{C}\right)$.

\section{Antiserum and virus}

Polyclonal rabbit antiserum to the yellow strain of CMV (CMV-Y) was used in all the experiments. The antiserum was absorbed with insolubilized healthy tobacco leaf proteins before use. For DAS-ELISA, y-globulin was purified from the absorbed antiserum by ammonium sulfate precipitation followed by DEAE cellulose colum chromatography (Clark and Bar-Joseph, 1984). In DIBA test, y-globulin solution was absorbed with extract of healthy tobacco leaves to eliminate trace amount of antibodies against healthy components. The antiserum of CMV-Z (serotype P) was also used in SDD test.

Double antibody sandwich enzyme-linked immunosorbent assay (DAS-ELISA)

DAS-ELISA was performed essentially as described by Clark and Adams (1977) with slight modifications. Wells of polystyrene microtiter plates were coated with y-globulin $(2 \mu \mathrm{g} / \mathrm{ml})$ for $3 \mathrm{hr}$ at $30^{\circ} \mathrm{C}$. The crude extract was triturated ca. $0.05 \mathrm{~g}$ dried samples in $0.5 \mathrm{ml}$ of sample buffer on Parafilm by using glass rods. An amount of $30 \mu 1$ of homogenate was poured in each well of plates containing $120 \mu 1$ of sample buffer and incubated overnight at $4^{\circ} \mathrm{C}$. The enzyme conjugate $(1: 800$ dilution) was reacted for $3 \mathrm{hr}$ at $30^{\circ} \mathrm{C}$. Artificially infected tobacco leaves with CMV-Y (dried 
samples) were used as positive control. The ELISA values were measured by using an ELISA analyzer (Immuno Reader NJ-2000, Inter med) at the wavelength of $405 \mathrm{~nm}$.

\section{Dot-immunobinding assay (DIBA)}

With some simple modifications, DIBA procedures were carried out following the method described by Powell (1987). Dried samples were macerated in TBS $(0.02 \mathrm{M}$ Tris-HCI, 0.5 M NaCl, pH7.5) on Parafilm with glass rods. Nitrocellulose membrane (NCM, Transfer Blot, Bio Rad) was immersed in distilled water and placed on filter paper for $5 \mathrm{~min}$ to dry. Two $\mu 1$ of extract was spotted on the NCM and dried for 10 min. The NCM was put in blocking solution consisted of $2 \%$ BSA (bovine serum albumin) and $2 \%$ Triton X-100 in TBS for $1 \mathrm{hr}$, followed by washing with TBST (TBS containing $0.05 \%$ Tween 20). The NCM was placed in a plastic box and $20 \mu 1 /$ grid of y-globulin $(2 \mu \mathrm{g} / \mathrm{ml})$ diluted with $1 \%$ healthy tobacco leaf extract in TBST containing $0.2 \% \mathrm{BSA}$ and $2 \%$ polyvinylpyrrolidone (antibody and conjugate buffer) was added and the membrane was incubated for $2 \mathrm{hr}$ at room temperature. The NCM was washed three times with TBST. The membrane was then incubated with goat anti-rabbit IgG-alkaline phosphatase conjugate diluted 2,000 times with the antibody buffer and washed as described earlier. The NCM was finally, incubated for 30-60 min in color development solution prepared by mixing fast red TR salt (Sigma) and naphthol AS-MX phosphate (Sigma) as recommended by Banttari and Goodwin (1985). The reaction was stopped by washing the NCM in distilled water after 30 min incubation and then air dried for visual observation.

\section{Simplified double-diffusion (SDD) test}

Some of the samples positive in DAS-ELISA and DIBA were tested by simplified double-diffusion test for sero-diagnosis of CMV. SDD test was performed as described by Shohara and Inoue (1978). The crude extract was prepared by macerating dried samples in $24 \%$ Noble Agar (Difco), $0.85 \% \mathrm{NaCl}$ and $0.2 \%$ sodium azide in $0.2 \mathrm{M}$ Tris-HCI buffer (pH7). The antiserum used in the experiment was diluted to, $1: 2$. Results were recorded after $22 \mathrm{hr}$ incubation at $30^{\circ} \mathrm{C}$. Hexagonal arrangement of wells was applied.

\section{Virus purification}

Two infective samples-cucumber (8) and chilli (21) propagated on cucumber and chilli, respectively were used for the purification of the virus. The virus was partially purified following the method described by Maeda et al. (1983) with some modifications. Infected leaves of cucumber and chilli were seperately used for purification. For each $100 \mathrm{~g}$ of leaves homogenized with mortar and pestle in $200 \mathrm{ml}$ of $0.5 \mathrm{M}$ citrate buffer ( $\mathrm{pH}$ 6.5) containing 0.025 M EDTA. Homogenate was filtered through doublelayered cheese cloth. The filtered extract was stirred for $20 \mathrm{~min}$ at $4^{\circ} \mathrm{C}$ with $1 / 5$ volume of chloroform followed by centrifugation at 5,000 g for $15 \mathrm{~min}$ and the supernatant was collected. The supernatant was stirred with $1 \%$ Triton-X 100 for $20 \mathrm{~min}$ and then $8 \%$ PEG was added. The mixture was centrifuged at $8,000 \mathrm{~g}$ for $20 \mathrm{~min}$ and collected the pellet. The pellet was resuspended in $0.005 \mathrm{M}$ sodium borate buffer $\mathrm{pH}$ 8.0) containing $0.005 \mathrm{M}$ EDTA followed by centrifugation at $8,000 \mathrm{~g}$ for $20 \mathrm{~min}$ and the supernatant was collected. A small amount of $20 \%$ sucrose was layered onto the 
borate-EDTA buffer follwing layering of virus suspension. This was then centrifugrd at $87,650 \mathrm{~g}$ in Hitachi $65 \mathrm{P}$ ultracentrifuge (RPS $65 \mathrm{~T}$ rotor) for $90 \mathrm{~min}$. The pellet resuspended in the borate-EDTA buffer contained the partially purified virus.

\section{Electron microscopy}

The partially purified virus was fixed with $2 \%$ formaldehyde and negatively stained with $2 \%$ uranyl acetate or $2 \%$ phosphotungstic acid $(\mathrm{pH} 6.0)$. The particle size was measured by a transmission electron microscope (JEM-100 S, JEOL Ltd.).

\section{RESULTS}

\section{Inoculation test}

Ten different samples marked with asterisk in Table 1 were found to be infective when inoculated to their original hosts in the greenhouse. All others remained inactive in repeated inoculation. Among these ten infective samples, one cucumber (Sample No. 8) and one chilli (Sample No. 21) were later confirmed as CMV. All other infective samples were identified as viruses other than CMV (our unpublished data).

On sap inoculation, both the virus isolates (cucumber, Sample No. 8 and chilli, Sample No. 21) produced local lesions on Chenopodium quinoa, C. amaranticolor, Gomphrenaglobosa and Pisum sativum typical for CMV. The isolates also induced mosaic symptoms typical for CMV on the leaves of inoculated $\mathrm{N}$ icotiana tabacum (White burley, Xanthi and Samsun NN), N. glatinosa, cucumber and chilli (Jones, 1988 ; Phillips and Rrunt, 1985 ; Tobias et al., 1982).

\section{DAS-ELISA}

Out of 92 samples tested, eight samples were found to be CMV-positive in DAS-ELISA (Table 2). Positive samples included the samples representing the four plant species such as cucumber, chilli, pepper and tomato among the 39 different plant species tested.

\section{DIBA}

All the samples tested by DAS-ELISA were included in the DIBA. The positive reactions were recognized by the appearence of well-defined purple red spot on the

Table 2. Samples positive in DAS-ELISA, DIBA and SDD test.

\begin{tabular}{lccc}
\hline Plant samples & DAS-ELISA & DIBA & SDD test \\
\hline *Cucumber (8) & + b) & + & + \\
Cucumber (9) & + & + & + \\
Chilli (18) & + & + & rlt \\
Chilli (20) & + & t & + \\
*Chilli (21) & + & + & + \\
Pepper (29) & + & + & $\mathrm{nt}$ \\
Tomato (30) & + & & \\
Tomato (32) & + & & \\
\hline
\end{tabular}

*): Infective sample in inoculation test.

a): Sample number in table 1 .

b) $:+$ : Positive reaction, - : Negative reaction, nt : Not tested. 


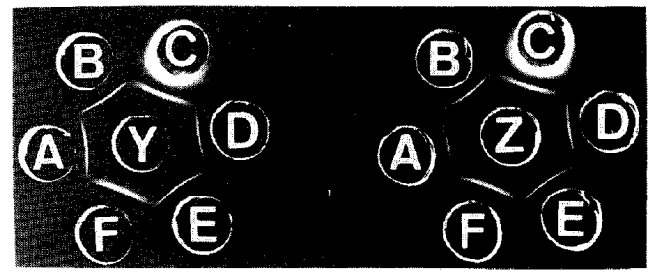

Fig. 1. Simplified double-diffusion (SDD) test by using dried sample. Y, Antiserum of CMV-Y ; Z, Antiserum of CMV-P ; A, Chilli (Sample No. 20 ; B, CMV control sample; C, Cucumber (Sample No. 8); D. Chilli (sample No. 21), E, CMV control sample; F, Cucumber (Sample No. 9).

nitrocellulose membrane. Results of DIBA are summarized in Table 2. In total six samples were found to be positive in DIBA. Two samples positive in DAS-ELISA were reacted negtatively in DIBA. Appearence of non-specific reactions has been reported as only problem in DIBA was successfuly eliminated by absorbing antisera with $1 \%$ healthy leaf extracts.

\section{SDD test}

As shown in Table 2 and Fig 1, four different samples out of six tested, produced distinct precipitin bands in SDD test. Two samples found to be positive in DAS-ELISA and DIBA did not produce any precipitin bands in SDD test.

\section{Electron microscopy}

The isometric virus particles measuring about $30 \mathrm{~nm}$ in diameter were observed under electron microscope from partially purified cucumber and chilli samples.

\section{DISCUSSION}

The results of this study demonstrated the occurrence of CMV on cucurbitaceous (cucumber) and solanaceous (chilli, pepper and tomato) plants in Bangladesh. Several other samples of different plant species including Leguminosae and Cruciferae reacted negatively, though these two families reported to have the highest numbers of hosts susceptible to CMV (Franki et al., 1979 ; Lovisolo, 1981). Moreover, the frequency of CMV positive samples even in cucurbits sand solanaceous plants were not so high (8/ 37) in this study. Hot-humid-tropical climate of Bangladesh might be one of the reasons of low prevalence of the virus there, as Lovisolo (1981) reported the high prevalence of CMV specially in the temperate zone.

Three serological methods, DAS-ELISA, DIBA and SDD test, were found to be useful for the detection of CMV from dried samples. The loss of infectivity of the virus during storage did not interfere with the detection of antigenicity in serodiagnosis. The highest number of samples, eight were found to be CMV positive in DAS-ELISA followed by six in DIBA and four in SDD test. Results suggested DAS-ELISA was the highest in sensitivity of DAS-ELISA as compared to two other methods used. The superiority of DAS-ELISA as a serological method over any others has been reported 
by many researchers (Clark, M. F. 1981; Clement et al., 1986). However, Ozyanar and Sako (1987) reported the equal sensitivity of DAS-ELISA and DIBA in detecting CMV, when they used either purified virus or crude leaf extracts of artificially inoculated plants in which the antigen concentrations and specificity were expected to be high compared to field samples used in our experiments. SDD test was found to be less sensitive than either of the methods.

Six CMV positive samples out of eight were found to be inactivated in storage within 223 years. McKinny et al. (1965) reported that CMV remained infective up to 15 years in storage. However, it has been reported that the longevity of virus infectivity varied with many factors such as host plants, drying methods, storage conditions etc (McKinny and Silber, 1968). Moreover, in our case, drastic change of temperature condition for several days during transportation of the samples from Bangladesh to Japan might be one of the main cause of inactivation of the virus.

In our study, the samples were irregular in number and limited in respect of plant species and areas surveyed. The high prevalence of CMV in Bangladesh may be expected in winter crops as the virus was reported to be common in the temperate zone.

However, to draw a sound conclusion on the occurrence of CMV in Bangladesh requires extensive survey considering the epidemiology and host range of the virus. Results of our study was suggestive, rather than conlusive to take well-planed research on CMV in Bangladesh.

\section{ACKNOWLEDGEMENT}

The authors are thankful to Dr. T. Kawarabata, Kyushu University for his technical help and advises during experiments. Thanks are due to Dr. S. H. Khan and Dr. I. H. Mian, Institute of Post-Graduate Studies in Agriculture, Bangladesh for cooperating at the time of sample collection in Bangladesh.

\section{REFERENCES}

Ahmed, H. U. 1984 Disease problems of pulse and oil-seed crops in Bangladesh. A paper presented in First Biennial Conference (held on 13-14) of Bangladesh Phytopathological Society, $18 \mathrm{pp}$

Ahmed, M. U. 1984 Diseases of vegetables and fruit plants. A paper presented in First Biennial Conference (held on December 13-14) of Bangladesh Phytopathological Society, $18 \mathrm{pp}$

Banttari, E. E. and P. H. Goodwin 1985 Detection of potato virus S, X, and Y by enzyme-linked immunosorbent assay on nitrocellulose membrane (DOT-ELISA). Plant Dis., 69: 202205

Clark, M. F. 1981 Immunosorbent assays in plant pathology. Ann.Rev. Phytopath., 19: X3-106

Clark, M. F. and A. N. Adams 1977 Characteristics of microplate method of enzyme-linked immunosorbent assay for the detection of plant viruses. J. Gen. Virol., 34: $475-483$

Clark, M. F. and M. Bar-Joseph 1984 Enzyme immunosorbent assays in plant virology. Meth. Virol., 7: 5185

Clement, D. L., R. M. Lister and J. E. Foster 1986 ELISA-based studies on the ecology of barley yellow dwarf virus in Indiana. Phytopathology '76:86-92

Cohen, S. 1982 Resistance to transmission of aphid-borne non-persistent viruses in vegetables. Acta Hort., 127: 117-124

Conti, M. and 0. Lovisolo 1982 Virus problems in protected vegetable crops. Acta Hort., 127:83-100 
Fakir, G. A. 1984 Plant disease problems of Bangladesh. A Keynote paper presented in First Biennial Conference (held on December 13-14) of Bangladesh Phytopathological Soc., 9 pp

Francki, R. I. B., D. W. Mossop and and T. Hatta 1979 Cucumber mosaic virus. CMI/AAB Descriptions of Plant Viruses No. 213, CMI, KEW, Surry, England 6 pp

Jones, R. A. C. 1988 Seed-borne cucumber mosaic virus infection of narrow-leafed lupin (Lupinus angustifolius) in western Australia. Ann. app. Biol., $113: 507-518$

Lovisolo, 0. 1981 Virus and viroid diseases of cucurbits. Acta Hurt., $88: 33-90$

Maeda, T., S. Wakimoto and N. Inouye 1983 Serological properties of cucumber mosaic virus in Japan. Ann. Phytopath. Soc. Japan $49: 10-17$

Martelli, G. P. and A. Quacqarelli 1982 The present status of tomato and pepper viruses. Acfa Hurt., $127: 39-64$

McKinny, H. H., G. Silber 1968 Methods of preservation and storage of plant viruses. Meth.Virol., 4 : 491-501

McKinney, H. H., G. Silber and L. W. Greeley 1965 Longeivity of some plant viruses stored in chemically dehydrated tissues. Phytopathology $55: 10431044$

Mclaughlin, M. R. and R. D. Ensign 1889 Viruses detected in forage legumes in Idaho. Plant Dis., 73 : 906-909

Ozyanar, F. and N. Sako 1987 The detection of cucumber mosaic virus strains by enzyme-linked immunosorbent and dot-immunobinding assays. Bull. Fac. Agri., Saga Univ., 62 :109-115

Phillips, S. and A. A. Brunt 1985 Occurrence of cucumber mosaic virus and asparagus virus II in asparagus (Aparagus officinalis L. var. officinalis) in Britain. Plant Pathol., 34 : 440-442

Powell, C. A. (1987). Detection of three plant viruses by dot-immunobinding assay. Phytopathology $77: 306^{-309}$

Rabbani, A. K. M. G. (Ed. ) 1984 Yearbook of Agricultural Statistics of Bangladesh. Govt. of Bangladesh, Dhaka, Bangladesh $505 \mathrm{pp}$

Rashid, H. 1981 An Economic Geography of Bangladesh, University Press Litd. Red Cross Building, 114/Motijiheel C. A., Dhaka, Bangladesh 276 pp

Rashid, M. M. 1976 Vegetables in Bangladesh (in Bengali). BARI, Joydebpur, Bangladesh 409

Shohara, K. and T. Inouye 1978 Simplified immunodiffusion tecniques in agar gel for detection and serodiagnosis of cucumber mosaic virus. Ann. Phytopath.Soc. Japan 44 : 619-625

Talukder, M. J. 1974 Plant diseases in Bangladesh. Bangladesh J. Agri.Res. 1:61-86

TARC (Tropical Agriculture Research Center) 1977 Symposium on the virus diseases of tropical crops. Trop. Agri. Res. Ser. No. 10, TARC, Ibaraki, Japan 208

Tobias, I., D. Z. Maat, and II. Huttinga 1982 Two Hungarian isolates of cucumber mosaic virus from sweet pepper (Capsicumannum) and melon (Cucumismelo): identification and antisera preparation. Netherland J. PI. Pathol., 88: 171-183. 